ANNA GuLCZYŃSKA

ORCID 0000-0003-4317-4839

Uniwersytet im. Adama Mickiewicza

$w$ Poznaniu

\title{
ZMIERZCH INTERAKCJI INSTRUKTYWNEJ. W STRONĘ AUTONOMII W DIALOGU RODZICE - NAUCZYCIELE
}

ABSTRACT. Gulczyńska Anna, Zmierzch interakcji instruktywnej. Wstronę autonomii w dialogu rodzice - nauczyciele [Decline of Instructive Interaction. Towards the Autonomy in the Parents-Teachers Dialog]. Studia Edukacyjne nr 52, 2019, Poznań 2019, pp. 273-290. Adam Mickiewicz University Press. ISSN 1233-6688. DOI: $10.14746 /$ se.2019.52.18

The theoretical background of the parents-teachers relation is systemic approach. It is the basis for a critical analysis of the pedagogization idea, treated as instructive interaction. Expert interaction between parents and teachers was proposed. The proposal of those relations based on the healing orientation by K. Ludewig was presented at the end of the article. The practical aim is to generate reflection and eventually activities to implement the particular suggestions in teachers' pedagogical work.

Key words: pedagogization, instructive interaction, parents, teachers, expert interaction, systemic approach

\section{Systemowy zarys koncepcji}

Kanwą teoretyczną poniższych rozważań będą koncepcje związane z podejściem systemowym - zgodnie ze stwierdzeniem, że

myślenie systemowe nie jest teorią, lecz raczej „superteorią” w rozumieniu Luhmanna. Dotyczy ono aktu ontologicznego i epistemologicznego określenia pozycji, a więc "sposobu widzenia” (Steier), "paradygmatu” (Kuhn), „kultury" (Wittgenstein, Maturana). Z perspektywy metodologii i praktyki życiowej wyodrębnia zakres "tego, co oczywiste" (Hofstaetter), pokazuje kontekst informacji, które sterują procesami kontaktów międzyludzkich i codzienną komunikacją ${ }^{1}$.

\footnotetext{
${ }^{1}$ K. Ludewig, Terapia systemowa, podstawy teoretyczne i praktyka, Gdańsk 1995, s. 59-60.
} 
Integrując założenia teorii systemowych - związanych zarówno z cybernetyką I rzędu, jak i cybernetyką II rzędu - opartą na konstrukcjonizmie społecznym, zasadne wydaje się przytoczenie kilku stwierdzeń, konstytuujących przyjęty paradygmat, w podejmowanym temacie relacji rodzice - nauczyciele. Każdy człowiek składa się z wielu systemów i każdy żyje w wielu systemach. Systemy mają swoją organizację wewnętrzną, co powoduje, że są czymś więcej niż tylko sumą poszczególnych elementów. Jednostka uczestniczy, w tym samym czasie, w wielu różnych systemach - wpływając na owe systemy i jednocześnie znajdując się pod ich wpływem. Zatem, większość zdarzeń czy interakcji ma charakter cyrkularny, a nie liniowy, stąd ustalenie, co stanowi przyczynę a co skutek jest bardzo trudne, jeśli nie niemożliwe, kiedy mówi się o systemach otwartych. Do systemów otwartych należy zarówno człowiek, jak też inne systemy społeczne, w których uczestniczy. W systemach żywych, czyli otwartych, stan początkowy nie determinuje stanu końcowego. W systemach nieożywionych, mechanicznych mówi się o tego rodzaju liniowości przyczynowo-skutkowej. Zatem, nie można przewidzieć i zaplanować ani interwencji, ani życia, ani porad dla innych osób w instytucjach pomagania, które będą idealnie pewnie, cudownie dopasowane, wspaniale skuteczne i zupełnie pewne. Ograniczone możliwości poznania drugiego człowieka (wynikające zarówno z biologii, jak i z samej natury poznania, w tym języka), zrozumienia go, a tym bardziej wydania dopasowanych instrukcji, czy idealnych porad, nakładają na pomagających pewne ograniczenia, a także wymagają, aby pozbyli się oni ułudy władzy.

Każdy człowiek wchodząc w relacje, niejako „wkłada” w nie cały swój system - zarówno system przekonań, jak i system zbudowany z systemów oraz interakcji, w których uczestniczy i które zmieniają go. Zmiana jednego elementu w systemie powoduje jakąś zmianę innych elementów systemu, jednak dokładne przewidzenie charakteru owej zmiany jest niemożliwe. Relacje pomagania są szczególnym rodzajem relacji, ponieważ najczęściej czynią one różnicę, poprzez którą ma miejsce zmiana. Owa różnica jest związana z komunikacją, a zatem - język stanowi podstawę wszystkich oddziaływań. Znaczenie słowa - tego, w jaki sposób będzie używane i tworzone - konstruuje rzeczywistość obserwatora. W związku z tym wrażliwość na język, pokora w zakresie wydawania sądów, świadomość własnych ograniczeń i ograniczonych możliwości zrozumienia oraz poznania innego człowieka stanowią tylko niektóre $\mathrm{z}$ istotnych twierdzeń teorii systemowych, ważne przy współpracy dwóch systemów, jakim są rodzice i nauczyciele z uwagi na trzeci system (lub podsystem), jakim są dzieci lub uczniowie (system ten jest innym systemem w zależności od tego, który system orzeka, nosząc inną nazwę, implikuje inne oczekiwania, emocje i reguły). 
Przekładając zasady teorii systemowych na warunki szkolne, należy zwrócić uwagę na to, że szkoła jest systemem, w ramach którego spotykają się osoby z różnych systemów, pozostających w ciągłej dynamice. Na przykład, w relacjach rodzice - nauczyciele chodzi o system „dzieci, które uczę w szkole", który jednocześnie dla uczestników innego systemu jest systemem lub podsystemem "moje dziecko". Czasami jest to stworzony w danej chwili system "dzieci, które wdały się w bójkę" lub system zbudowany z uwagi na przyjęte odgórnie kryterium - „szóstkowi uczniowie w naszej klasie”. System rodzice i system nauczyciele to dwa systemy równorzędne. System rodzice - dzieci to system złożony z podsystemów lub systemów z przypisaną kategorią władzy, podobnie system nauczyciele - uczniowie jest hierarchiczny i nierówny. Już z samego powyższego przykładu widać, że dzieci występują tu czasami w podsystemie/systemie - uczniowie oraz podsystemie/systemie - moje dzieci. Ich rola jest zmienna, podległa, a ów brak równowagi nie jest niczym zaskakującym, ale co ważniejsze - zasadne jest go dostrzegać, szanować i z wiedzą o mechanizmach z niego korzystać.

Co warte szczególnego podkreślenia, a będzie analizowane w dalszej części, to fakt równości systemu rodzice z systemem nauczyciele. Są to systemy odrębne, częściowo zależne; nie można wskazać jednak, kto zawsze ma rację, kto wie lepiej, kto zna się na życiu, kogo zawsze słuchać i kto zawsze poniesie konsekwencje - zarówno prawne, jak i moralne określonych decyzji czy działań. Idea ta będzie towarzyszyć całemu artykułowi, gdyż wydaje się niezwykle istotna dla zrozumienia współtworzenia relacji rodzice - nauczyciele, w przeciwieństwie do jej skośnego, hierarchicznego układu, który zakładany jest w ideach pedagogizacji.

\section{Interakcje instruktywne - wolność wyboru czy ciężkie ograniczenie?}

Sformułowanie "relacja/interakcja instruktywna” w ujęciu pedagogicznym nie było dotąd stosowane. Zdecydowano się je użyć z dwóch względów. Po pierwsze, wywodzi się ono z systemowego myślenia o procesach społecznych i człowieku, które są bazą niniejszych rozważań. Po drugie, jest zbieżne z opisywanymi zjawiskami, które mają miejsce w polskiej szkole, w kontaktach rodzice - nauczyciele, czyli z relacją opartą na umoralniającej, mentorskiej - przyjętej lub nadanej - roli nauczycieli.

Sformułowanie racja instruktywna wprowadzone było przez Maturanę, który zachęcał do porzucenia relacji instruktywnych w pracy z drugą osobą, a dostrzegania różnorodności, wielu wzorców i możliwych dróg. Stwierdza 


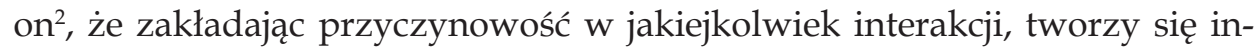
terakcja instruktywna - pouczająca. Zakłada ona liniowość i zależności przyczynowo-skutkowe, od których odchodzi się w koncepcjach systemowych. Dell ${ }^{3}$ dodaje, że prawdopodobnie dychotomia: interakcja pouczająca vs determinizm strukturalny stanie się ważniejsza w tłumaczeniu zjawisk społecznych niż dychotomia przyczynowo-skutkowa vs linearna. Stwierdza on również, że interakcja pouczająca jest ontologicznie niemożliwa (choć być może lepiej byłoby stwierdzić nieskuteczna, bezzasadna, czy rozczarowująco bezskuteczna), ponieważ nie żyjemy w świecie liniowych zależności.

Osadzając się w kategoriach konstruktywizmu epistemologicznego, Kraus ${ }^{4}$ stwierdza, że skuteczność interakcji pouczającej jest pewnego rodzaju mitem. Informacja, prośba, czy też interakcja zawsze ma tylko znaczenie zakłócenia. Decyzja, jak zareagować na to zakłócenie, pozostaje w rękach adresata owej interakcji, czyli jak pisze Kraus - domniemanego bezsilnego, któremu udziela się instruktażu. Autor ten dodaje, że nawet domniemany bezsilny może odrzucić każdą prośbę, aczkolwiek czasami za bardzo wysoką cenę. Proponuje on podzielenie wpływu na dwie grupy - mające moc instruktażową oraz mające moc destruktywną. Istniejąca różnica w jakości między działaniami pouczającymi a niszczycielskimi w zakresie wywierania wpływu wynika z możliwości odmowy. Siła niszcząca ogranicza możliwości danej osoby, podczas gdy siła pouczająca i oparta na niej relacja ma na celu instruowanie innej osoby. Relacja instruktażowa może być skuteczna jako konstrukcja społeczna, chociaż osoby poinstruowane mogą odrzucić wszelkie pouczające wysiłki.

W odniesieniu bezpośrednio do tematu artykułu - nawet jeśli intencjami nauczycieli jest zapewnienie pomocy - często wiąże się z próbami „poinstruowania" rodziców. Kraus formy pomocy, w których specjaliści ustalają cele, jakie powinni osiągnąć adresaci określa jako „pouczającą kontrolę". Wysiłki kontrolne, których celem jest pouczająca interakcja, nazywane są instruktażową kontrolą, natomiast wysiłki kontrolne, które działają przeciwnie poprzez zmniejszenie szans, nazywane są kontrolą destrukcyjną. Kontrola pouczająca przedstawia próby mające na celu wywołanie określonych reakcji, podczas gdy zapobieganie zachowaniom za pomocą destrukcyjnej interakcji zalicza się do kontroli destrukcyjnej. Pod tym względem instruktażowa kontrola opiera się na pouczającej mocy, a niszcząca kontrola - na niszczycielskiej sile. Kontrola pouczająca może mieć na celu zapobieganie niepożądanym działaniom, jak

${ }^{2}$ H.R. Maturana, B. Poerksen, The view of the systemicist: a conversation, Journal of Constructivist Psychology, 2004, 17, s. 269-279.

${ }^{3}$ P.F. Dell, Why family therapy should go beyond homeostasis: A Kuhnian reply to Tyano, Carel and Ariel, Journal of Marital and Family Therapy, 1984, 10, s. 351-356; tenże, Understanding Bateson and Maturana: toward biological foundation for the social sciences, Journal of Marital and Family Therapy, 1985, 11, 1, s. 1-20.

4 B. Kraus, Introducing a Model for Analyzing the Possibilities of Power, Help and Control, Social Work \& Society, 2014, 12, 1, s. 1-12. 
również podejmowanie pożądanych działań. Niszcząca kontrola może jednak zawsze i tylko wymuszać zapobieganie niepożądanym działaniom.

Ze względu na strukturalne sprzężenie człowieka z jego systemem, warunki środowiska są kluczowe dla budowy subiektywnej rzeczywistości życia. Właśnie dlatego dana osoba jest odpowiedzialna za wybór dostępnych alternatywnych rozwiązań, które faktycznie są do jej dyspozycji. Oczywiście, z perspektywy konstruktywistycznej nie można decydować, która droga i które wybory są właściwe. To, do czego zachęca autor, to rozwijanie i komunikowanie pomysłów na temat (mniej lub bardziej) obiecujących koncepcji życia, czyli po prostu - do dialogu.

\section{Systemowe współzależności - rodzice i nauczyciele}

Rodzina i szkoła to dwie najbliższe dzieciom struktury formalne. W rzeczywistości społecznej, w której Internet zamienił się rolą z blokowym podwórkiem, czy spędzaniem czasu z rówieśnikami w pozaformalnych warunkach, szkoła i rodzina stały się - tym bardziej - dwoma głównymi miejscami socjalizacji. Zapracowani, zajęci własnym rozwojem osobistym, czy zwykłymi sprawami domu, rodzice mają mało czasu na spędzenie go w kontakcie z dzieckiem ${ }^{5}$. Po wykonaniu zwykłych i niezwykłych zadań dnia codziennego lub zaplanowanych na weekend zakupów, odwiedzin, kina, czy restauracji, pozostaje niewiele czasu na kontakt w ramach rodziny, często zarówno z partnerem/partnerką, jak i oczywiście dzieckiem/dziećmi. Stąd też wywodzi się obserwowalna zmiana pozycji dziecka w rodzinie i jego rolí.

Uwzględniając zarówno przekształcenia w makrostrukturach, mikrostrukturach, jak i mezostrukturach, świat współczesny w niewielkim stopniu przypomina świat sprzed 20-30 lat. Bezpowrotnie zmienił się kontekst, w jakim te same albo inne procesy mają miejsce, zmieniły się systemy,

\footnotetext{
${ }^{5}$ M. Kędra, Wtaczanie rodziców w edukację dzieci

http://sp8chelm.pl/images/galerie/biblioteczka_dla_rodzicow/wlaczanie_rodzicow_w_ edukacje_dzieci.pdf [dostęp: 13.11.2018]; I. Chmura-Rutkowska, J. Ostrouch, Zakres i formy zaangażowania ojców w codzienne relacje $z$ dziećmi, [w:] Kierunki działań w Polsce na rzecz równowagi praca-życie-rodzina, red. C. Sadowska-Snarska, Białystok 2008, s. 209-228; M. Rokicka-Hebel, Aktywność wolnoczasowa dzieci w wieku przedszkolnym i ich rodziców, Rocznik Naukowy AWFiS w Gdańsku, 2014, XXIV, s. 19-34.

${ }^{6} \mathrm{~K}$. Segiet, Dziecko i jego dzieciństwo w perspektywie naukowego poznania i doświadczania rzeczywistości. Studium pedagogiczno-społeczne, Poznań 2011, rozdział II; taże, Dziecko i dzieciństwo jako wartość a wspótczesność, Chowanna 1, 2010, s. 129-137; J. Izdebska, Dziecko - dzieciństwo - rodzina - wychowanie rodzinne: kategorie pedagogiki rodziny w perspektywie pedagogiki personalistycznej, Białystok 2015; K. Segiet, K. Słupska, Zmiany w funkcjonowaniu wspótczesnej rodziny $i$ ich konsekwencje dla rozwoju młodego pokolenia, Pedagogika Społeczna, 2013, 3(49), s. 97-114; D. Żołądź-Strzelczyk, Dziecko w dawnej Polsce, Poznań 2002; M. Cywińska, Sytuacje trudne w życiu dziecka, część I, Poznań 2008.
} 
zmieniło znaczenie również dwóch najważniejszych agend socjalizacyjnych - jest ono bardziej zróżnicowane, mniej oczywiste i monadyczne. Analizując szeroko dostępne w Internecie przeróżne - zarówno co do ilości, jak i jak jakości - statystyki oraz opracowania, w których pojawia się pytanie: kto powinien dbać, żeby dzieci i młodzież..., respondenci odpowiadają zazwyczaj, że zarówno szkoła, jak i rodzice ${ }^{7}$. Zatem, niejako naturalną konsekwencją staje się wzrost oczekiwań, jakie stawiane są rodzicom przez nauczycieli oraz szkołę i nauczycielom przez rodziców. Niespełnione wzajemne oczekiwania nasilają się, poczucie nieadekwatności, rozproszenie odpowiedzialności, czy też unikanie wzrasta. W efekcie, owym dzieciom i młodzieży przeznacza się coraz mniej świadomych i będących odpowiedzią na ich potrzeby oddziaływań. Również zjawisko to ma swoje makro-, mikro- i mezouwarunkowania. A - zgodnie z opisaną powyżej teorią systemową - może przyczynić się do pretendowania przez jeden system do dominacji i uznania go za lepszy, czyli o większym zakresie władzy. W niejako naturalny sposób drugi system oceniony zostanie jako gorszy, zależny, podległy.

Z jednej strony wspomniani wcześniej rodzice, z drugiej - nauczyciele, których praca nie należy ani do łatwych, ani do bardzo dobrze wynagradzanych, przemęczeni dodatkowymi godzinami, kontynuowaniem działań w domu, stają się coraz mniej zdolni do pełnego kontaktu i zaangażowania w swoją pracę. Obydwa systemy - osłabione, często nastawione antagonistycznie - nie działają razem dla dobra dzieci. Zatem, mówiąc o współpracy nauczycieli i rodziców (opiekunów prawnych), konieczne jest podkreślenie ich kooperacji, koordynacji, współ-wykonywania pewnej pracy. Niestety, artykuł ten będzie kolejnym wysuwającym propozycje dla nauczycieli i/lub osób kształcących nauczycieli. A w związku z tym - niejako już z założenia przesuwającym punkt ciężkości owego wyjścia $\mathrm{z}$ inicjatywą $\mathrm{w}$ stronę nauczycieli. Być może będzie też propozycją niosącą ulgę w trudnej szkolnej rzeczywistości, podejmującym każdego dnia wyzwania, wielu zaangażowanym nauczycielom.

\section{Rodzice i nauczyciele - historia i teraźniejszość}

Badania nad relacją rodziców i nauczycieli mają w Polsce długą historię̨ Celem takich kontaktów ma być w zamierzeniu "tworzenie spójnych, bezpiecznych i przyjaznych warunków do edukacji i wychowania oraz dbałość

${ }^{7}$ https://www.cbos.pl/SPISKOM.POL/2014/K_093_14.PDF; https://www.cbos.pl/SPISKOM.POL/2009/K_121_09.PDF; J. Kołodziejczyk, H. Cieślak, Analiza wyników ewaluacji zewnętrznych w odniesieniu do wymagania "Rodzice sa partnerami szkoty", https://www.npseo.pl/ data/various/files/tom4_roz11.pdf

${ }^{8}$ W. Segiet, $O$ zwiazzku edukacji z rodzina. Społeczne konteksty i jednostkowe biografie, Poznań 2013, s. 87-107 i 169-184; tenże, Rodzice - nauczyciele. Wzajemne stosunki i reprezentacje, Warszawa 
o prawidłowy i harmonijny rozwój dziecka" ${ }^{\prime 9}$. Jednak relacje te, przepełnione stereotypami i zaszłościami historycznych form współpracy, przyczyniają się raczej do braku kontaktu niż wzmacniania współpracy ${ }^{10}$. W celu stworzenia owej współpracy, czy też współdziałania, konieczne jest podjęcie określonych działań, opartych na komunikacji. Owo „nawoływanie” do komunikacji staje się w wielu publikacjach priorytetowe. Autorzy jednogłośnie podkreślają jej znaczenie $\mathrm{w}$ tworzeniu bezpiecznego środowiska dla rozwoju i kształcenia dzieci $^{11}$. Jednocześnie piszą o dominującej w polskiej szkole jednokierunkowej komunikacji z rodzicami ${ }^{12}$. Antyprzykładów czy opisów złych praktyk $\mathrm{w}$ literaturze przedmiotu jest wiele ${ }^{13}$. Przy toczone zostaną tylko wybrane, ponieważ większość dostępnych publikacji dotyczy głównie diagnozy oraz opisów kłopotów, trudności i braków, a także postulatów, z których większość jest niemożliwa do zrealizowania. Jeden z antyprzykładów stanowi dokonana analiza rodzajów komunikatów znajdujących się w szkolnych "zeszytach kontaktów”, pomyślanych jako „narzędzie współpracy, porozumienia i wymiany komunikatów pomiędzy szkołą a rodzicami o postępach uczniów oraz o sprawach organizacyjnych i opiekunczo-wychowawczych"14. W konkluzji można przeczytać, między innymi, że w korespondencji ze strony nauczycieli dominuje odmiana stylu urzędowego, pojawiają się błędy językowe, a także naruszanie zasad „współpracy konwersacyjnej”, w analizowanych materiałach nie ma ani jednego wzmocnienia pozytywnego ucznia ${ }^{15}$.

Niektórzy wprost powątpiewają w możliwość zbudowania relacji opartych na wspólnocie wartości i wizji pracy szkoły ${ }^{16}$. Inne badania przepro-

1999, s. 23-33 i 50-67; A.W. Janke, Transformacja w stosunkach rodziny i szkoty na przełomie XX i XXI wieku, Bydgoszcz 2002, s. 119-143.

${ }_{9} \mathrm{M}$. Zielińska, Interpersonalne kontakty nauczycieli z rodzicami w dobie dziennika elektronicznego, Edukacja - Technika - Informatyka, 2017, 3/21 s. 159.

10 A. Błasiak, Wspótpraca szkoły i rodziny jako istotny czynnik optymalizacji procesów wychowania i kształcenia najmłodszego pokolenia, Horyzonty Wychowania, 2017, 16, 38, s. 19-20; B. Lulek, Powinności - Pozory - Inicjowanie działania. Wyznaczniki relacji rodziców z nauczycielami w szkołach podstawowych, Kultura - Przemiany - Edukacja, 2017, V, s. 199-200.

${ }^{11} \mathrm{~K}$. Hernik, K. Malinowska, Jak skutecznie wspótpracować $i$ komunikować się z rodzicami i spotecznościa lokalną. Poradnik dla nauczycieli i dyrektorów, Instytut Badań Edukacyjnych, Warszawa 2015, s. 12-48.

${ }_{12}$ Tamże, s. 8-12; J. Miąso, Starcie paradygmatów technologii informacyjnych i komunikacji interpersonalnej bezpośredniej wyzwaniem dla człowieczeństwa, społeczeństwa i edukacji, Edukacja - Technika - Informatyka, 2015, 3(13), s. 47-52.

${ }^{13}$ Por zestawienie dokonane przez bibliotekę w Poznaniu: http://www.pbp.poznan. pl/node/355 oraz zestawienie: ww.pbw.kielce.pl/userfiles/file/nowe_zestawienia/dokument138.pdf

${ }_{14}$ B. Szczerbińska, Zeszyt kontaktów jako narzędzie komunikacji szkolnej, Kształcenie Językowe Dydaktyka Polonistyczna, 2017, 3(12), s. 228.

${ }_{15}$ Tamże, s. 241.

${ }^{16}$ Polak, 2013, s. 350, 352 za: M. Zielińska, Interpersonalne kontakty nauczycieli z rodzicami. 
wadzone na nauczycielach wskazują, że rodzice najchętniej w kontaktach ze szkołą wykorzystują zebrania ogólne (wywiadówki - 85\% wskazań), rozmowy indywidualne $z$ nauczycielem (konsultacje - 55\%) oraz dziennik elektroniczny $(43 \%)^{17}$. Niewątpliwie, zadziwiający jest fakt, że z grupy zbadanych 141 nauczycieli „żaden nie upatruje przyczyn braku efektywnej współpracy po stronie nauczycieli”, za jej brak „obwiniani są rodzice lub usterki zewnętrzne"18. Co więcej,

nauczyciele zbudowali sobie obraz rodzica roszczeniowego bądź obojętnego, z jednoczesnym brakiem refleksji na temat własnych uchybień, co nieuchronnie prowadzi do porażek (komunikacyjnych) we wzajemnych interakcjach. W myśl zasady: ja robię, co mogę, tylko to ten zły rodzic... ${ }^{19}$.

W Polsce pokutuje, a może wciąż jest aktualne, pojęcie pedagogizacji, będącej przejawem relacji instruktywnej, pomyślanej jako instrukcja dla rodziców pochodząca od lepiej wykształconego nauczyciela.

Rodzice postrzegani są jako mniej kompetentni wychowawcy własnego dziecka, którzy dysponują jedynie wiedzą potoczną. Nauczyciele natomiast określają siebie jako profesjonalistów od wychowania. Szkoły mają tendencję do kontrolowania, nierzadko nadmiernego, działań organów rodzicielskich. Ponadto występuje rozbieżność wzajemnych oczekiwań zaangażowanych stron, pozorność działań rodzicielskich organów w szkole - powoływanych obligatoryjnie i mających ograniczony obszar samodzielnego działania, brakuje upowszechniania dobrych praktyk w omawianym zakresie, a także brak miejsca wyodrębnionego tylko dla rodziców ${ }^{20}$.

Zatem, mimo upływu lat wciąż żywa jest idea, że działalność powinna zmierzać do „stałego wzbogacania przez rodziców potocznej wiedzy pedagogicznej o elementy naukowej wiedzy o wychowaniu dzieci i młodzieży"21, zaś bezpośrednia i pośrednia pomoc odzwierciedlać się w oddziaływaniach wychowawczych poprzez podniesienie świadomości pedagogicznej rodziców ${ }^{22}$. W dość epokowej, choć niezwykle często nadal cytowanej pracy Kawula $^{23}$ wymienił trzy zadania pedagogizacji, gdzie prowadzący działania pedagogizujące rodzinę powinien:

${ }_{17}$ B. Dusza, Sylwetka rodzica i jego wspótpraca ze szkoła w oczach nauczycieli gimnazjum (doniesienie z badań), Edukacja - Technika - Informatyka, 2017, 2/20, s. 189.

18 Tamże, s. 191.

19 Tamże.

${ }^{20}$ B. Lulek, Powinności - Pozory - Inicjowanie działania.

${ }^{21}$ A. Dzikomska-Kucharz, Pedagogizacja rodziców - zadanie szkoły, Edukacja i Dialog, 2001, 3, s. 7.

${ }^{22}$ S. Kawula, Pedagogizacja rodziców, [w:] Encyklopedia pedagogiczna, Wyd. 1. red. W. Pomykało, Warszawa 1993, s. 581.

${ }^{23}$ Tamże. 
- ukazywać problemy związane z wychowaniem ich dzieci (bez pedagogicznego przewodnictwa opiekujący się dziećmi nie byliby w stanie tych problemów prawidłowo zrozumieć lub nawet ich dostrzec);

- uczulać pedagogizowanych, aby przyswajaną wiedzę o wychowaniu stosowali we własnej praktyce wychowawczej;

- zaszczepić pedagogizowanym przyzwyczajenia i potrzeby samokształcenia się pedagogicznego.

Jest to o tyle trudne, czy wręcz niemożliwe, że współcześni rodzice mają dostęp do wiedzy - zarówno naukowej jak i potocznej - choćby poprzez korzystanie z mediów społecznościowych i forów. Warto zaznaczyć, że są wówczas aktywnymi poszukiwaczami informacji, nawet jeśli poziom znalezionych tekstów jest wątpliwej jakości ${ }^{24}$. Mogą zadawać pytania, dzielić się informacjami, pytać, czy po prostu nie zgadzać się (zamknięta grupa na Facebooku „rodzice nastolatków” liczyła we wrześniu 2018 roku ponad 9 tysięcy członków, z czego w codziennych rozmowach brało udział średnio 200 - 300 osób, natomiast wiele więcej zaznaczało, że „lubi to”. Jak zawsze pojawia się pytanie retoryczne: czy to dużo?).

Mimo upływu czasu, zmian społeczno-ekonomicznych, politycznych i cyfryzacji, publikacje o ważności i znaczeniu pedagogizacji promującej nierówne relacje są wciąż obecne $\mathrm{w}$ dyskursie naukowym. Owinięte w nowe słowa i nowe treści, zaprzeczają idei współpracy i współdziałania rodziców z nauczycielami. Nadal sprzyjają bierności rodziców i nadaktywności nauczycieli.

Pedagogizacja rodziców jest już dzisiaj trochę przestarzałym określeniem, ale jej założenia nie straciły na wartości. Realia wykazały jednak niechęć ze strony rodziny do uczestnictwa w projektach tego typu. O ile rodzice wykazują zainteresowanie placówką jeszcze na poziomie edukacji przedszkolnej czy wczesnoszkolnej, to na późniejszych etapach kształcenia wzrasta niechęć do kontaktów ze szkołą i zaangażowanie się we współpracę, mimo iż problemy narastają wraz i wymagają ścisłej kooperacji $\mathrm{z}$ domem ${ }^{25}$.

Należy jednak wyraźnie zaznaczyć - czym innym jest pedagogizacja, a czym innym współpraca, współdziałanie i kooperacja. Narzucając rodzicom pedagogizację, nie ma miejsca na współpracę i współdziałanie. Pedagogizacja zakłada krzewienie idei z pedagogiki i psychologii wśród rodziców, jednak rzadko spotyka się w literaturze przedmiotu stwierdzenie, że po rozpoznaniu ich (rodziców) potrzeb. O nich wnioskuje się arbitralnie, ustala je system, dyrek-

${ }^{24}$ M. Bereźnicka, Fora internetowe jako źródło informacji pedagogicznej wspótczesnych rodziców, [w:] Kultura informacyjna w ujęciu interdyscyplinarnym: teoria i praktyka, t. 2, red. H. Batorowska, Z. Kwiasowski, Kraków 2016, s. 274-284; D. Bis, Rodzina jako podstawowe środowisko wychowania do korzystania ze środków społecznego komunikowania, Roczniki Nauk Społecznych, 2002, XXX, 2.

${ }_{25}$ U. Ordon, A.K. Gębora, Partnerskie relacje rodziny i szkoty w tworzeniu optymalnych warunków procesu edukacji, Pedagogika Przedszkolna i Wczesnoszkolna, 2017, 5, 1(9), s. 61. 
tor, sam nauczyciel, pedagog, czy psycholog. Stąd trudno dziwić się rodzicom, którzy najpierw postrzegani są jako niedoświadczeni i wymagający autorytarnej pomocy, po czym mają stać się świadomymi wychowawcami i partnerami rozmowy. Autorzy artykułów promujących idee pedagogizacji zwracają uwagę na fakt, że podnoszenie kultury pedagogicznej rodziców jest bardzo istotne, gdyż staje się ona czynnikiem stymulacji rozwoju młodego pokolenia ${ }^{26}$ i należy:

wyposażyć rodziców w wiedzę z zakresu zagrożeń funkcjonowania młodzieży w „cyfrowym" świecie oraz sposobów nawiązywania, budowania relacji w rodzinie, rozpoznawania potencjału młodzieży, motywowania do rozwoju pasji i zainteresowań oraz aktywnego spędzania czasu wolnego; kształtować umiejętności aktywnego słuchania, empatii, rozpoznawania potrzeb i możliwości młodzieży, porozumienia bez przemocy w sytuacjach buntu i konfliktów, budowania więzi w rodzinie, poszukiwania wspólnych zainteresowań oraz konstruktywnego spędzania czasu wolnego wspólnie oraz indywidualnie ${ }^{27}$.

W literaturze pojawia się nawet sformułowanie ${ }^{28}$ pedagogizacja medialna, rozumiana jako element pedagogizacji rodziny, kształtowanie kompetencji medialnych jej członków zajmujących się wychowaniem dzieci lub nastolatków w obszarach:

- wychowania i kształcenia za pośrednictwem mediów, czyli możliwości wykorzystywania mediów do wspomagania kształtowania różnych sfer rozwojowych dziecka lub nastolatka oraz kształtowania jego systemu aksjonormatywnego (świata wartości), a więc w działaniach związanych z procesem jego edukacji;

- wychowania do mediów, to znaczy kształtowania kompetencji rodziców i opiekunów do podejmowania wielokierunkowych działań mających na celu zapewnienie maksymalnego bezpieczeństwa dziecku lub nastolatkowi korzystającemu z mediów przede wszystkim przez jego wychowanie, a w dalszej kolejności przez zabezpieczenia sprzętowe i programowe oraz kontrolę jego działań medialnych;

- edukacji medialnej rodziców i opiekunów, to znaczy kształtowania ich kompetencji medialnych ${ }^{29}$.

Mimo obszernego zakresu celów pedalizacji, opisu obszarów oraz zakładanych zmian u rodziców, nie ma informacji o rozpoznaniu potrzeb - zarówno w zakresie tematów, jak i metod, czy technik i narzędzi owych działań.

${ }^{26}$ S. Kawula, Kultura pedagogiczna rodziców: wyzwanie i czynnik stymulacji rozwoju młodego pokolenia Polaków, [w:] Edukacja prorodzinna. Księga dedykowana Profesorowi Marianowi Śnieżyńskiemu, red. M. Chymuk, D. Topa, Kraków 2000, s. 32-41.

${ }^{27}$ J.M. Łukasik, R. Solecki, Aktywność młodzieży w Internecie a relacje z rodzicami. Wskazania dla nauczycieli do pedagogizacji rodziców, Rocznik Lubuski, 2017, 43, 1, s. 175-189.

${ }_{28}$ M. Musioł, Pedagogizacja medialna rodziny: zakres - uwarunkowania - dylematy, Katowice 2013, s. 52-53.

29 Tamże. 
Nie jest możliwe pedagogizowanie rodziców i nawiązanie z nimi jednocześnie relacji współpracy. Pedagogizowanie mówi o relacji zależności: mądry nauczyciel i potrzebujący owej mądrości rodzic. Słowo pedagogizacja niesie ze sobą konkretny ładunek, zarówno semantyczny, praktyczny, jak i historyczny. Ma określone znaczenie, które nie jest neutralne. Wyznacza kierunek, określa zależność. Zatem, użycie słowa pedagogizacja oznacza narzucanie wiedzy, wchodzi w dyskurs władzy, dzieli na mądrzejszych i głupszych. Nie można stosować współdziałającej pedagogizacji ani kooperacyjnej pedagogizacji, ponieważ wydaje się być nie tylko oksymoronem, ale i absurdem. Konkludując, pedagogizacja jest interakcją instruktywną, pomija się $\mathrm{w}$ niej nie tylko rodziców jako znawców swojego dziecka, ale także ich potrzeby w zakresie wiedzy/porad/umiejętności oraz fakt, że są dorosłymi ludźmi, daleko poza subsystemem - uczniowie.

Artykuł ten ma być zarówno głosem w dyskusji, jak i służyć propozycji konkretnego podejścia do relacji rodzice - nauczyciele. W związku z tym postuluje się, aby spotkanie rodziców (opiekunów) i nauczycieli było spotkaniem dwóch grup ekspertów lub pary ekspertów. Nauczyciel/pedagog/ psycholog szkolny jest ekspertem od nauczania, od swojego przedmiotu, od procesów opiekuńczych i wychowawczych, od ucznia. Rodzic jest - takim albo innym - ekspertem od życia swojego dziecka, które w określony sposób wychowuje. Jest ekspertem od pokoju, w którym dziecko mieszka, od kupowania ubrań, od bycia $\mathrm{z}$ nim $\mathrm{w}$ relacji jeden na jeden, od bycia z nim w chorobie i sukcesach.

Niestety, ze względów historycznych, systemowych, w tym strukturalnych spotkanie eksperckie jest prawie niemożliwe. Często nauczyciel wie lepiej jak powinno być, wie co rodzic powinien zmienić i wie co robi źle. Jest ekspertem, który wchodzi w relacje nie-eksperckie z rodzicem, czującym się w wielu obszarach ekspertem. Relacja ekspercka, oparta na współdziałaniu i dialogu jest jedyną szansą w kontaktach na linii rodzice - szkoła. Rodzice mają słuchać, mają generować pomysły, mają przyjmować odpowiedzialność za realizację koncepcji nauczyciela co do ich dziecka w ich domu i w kontaktach z rówieśnikami. Nauczyciele czują się zmęczeni, wypaleni w pracy $\mathrm{z}$ „roszczeniowym rodzicem”, do którego nie umieją dotrzeć.

Powyższa analiza nie ma na celu wskazania sprawców i ofiar, lepszych czy gorszych. Nauczyciel znajdując się w określonych warunkach, podlega determinizmowi strukturalnemu (w rozumieniu Maturany), który wyznacza mu określoną pozycję w owych strukturach. Jednak sposób, w jaki będzie on organizował swoją współpracę, czy kooperację z rodzicami, zależy w dużej mierze od niego. Jako egzemplifikację warto wspomnieć o pewnym doświadczeniu, które prawdopodobnie miało miejsce w życiu wielu polskich rodziców, posiadających dziecko chodzące do szkoły. Podczas zebrań szkolnych rodzice 
siedzą w klasach na małych krzesłach, przy niskich ławkach, adekwatnych do wieku rozwojowego ich dzieci. Wraz z kolejnymi klasami szkoły podstawowej warunki te poprawiają się. Jednakże, rozmowa z pozycji wciśniętego w ławkę, z płaszczem przy boku, rodzica, który podobnie jak jego dziecko siedzi w pozycji podległej i ma słuchać, nie zachęca do dialogu, osłabia inicjatywę, pozbawia komfortu pracy również samych nauczycieli. Takie rozwiązania, jak odsunięcie ławek na bok, wykorzystanie ich do siedzenia, czy wręcz czasowe ich wyniesienie w polskich szkołach są zjawiskiem nieistniejącym.

\section{Rekomendacje, propozycje, alternatywy}

W zależności od zgłaszanej sprawy, czy mającej miejsce sytuacji, nauczyciel może wybrać różne opcje relacji z rodzicem. Rodzic przychodzi do nauczyciela zazwyczaj wówczas, kiedy "coś złego się dzieje”, pojawia się trudny do rozwiązania problem, o określonych reperkusjach. Nauczyciel - raczej nie chcąc niż chcąc - zostaje postawiony w pozycji mającego prawie "uleczyć dziecko", dać trafną radę rodzicowi i niczym lekarz - pomóc. Wynika to z opisanych wcześniej uwarunkowań, czy historii rodzice - nauczyciele i idei, że nauczyciel wie lepiej - niesionej zarówno przez system szkolny, samych nauczycieli, rodziców oraz dzieci. W związku z tym rola rodzica często bywa bliższa wizycie u lekarza - nauczyciela niż konsultanta i współuczestnika dialogu. Zatem, co Ludewig $^{30}$ napisał o zleceniach stawianych lekarzom, wydaje się być zleceniami, które są wysuwane wobec nauczycieli, czy też nauczyciele wysuwają je wobec samych siebie, ponieważ czasami trudno ustalić, zgodnie z rozumieniem systemowym, co było pierwsze. Parafrazując, nauczyciel:

z jednej strony powinien przyczyniać się do postępu sztuki edukacji, wprowadzając nowe metody nauczania [podkreślone wstawienia - AG]. Równocześnie powinien uchodzić za osobę zrównoważoną, zrozumiałą, godną zaufania. Inaczej mówiąc, oczekuje się od niego: „Zawsze coraz lepiej, ale w sposób zrozumiały”.

W oryginale brzmi to ${ }^{31}$ :

kto walczy z chorobami, musi odpowiadać na sprzeczne zapotrzebowania społeczne. $\mathrm{Z}$ jednej strony powinien przyczyniać się do postępu sztuki medycznej, wprowadzając nowe metody leczenia. Równocześnie powinien uchodzić za osobę zrównoważoną, zrozumiałą, godną zaufania. Inaczej mówiąc, oczekuje się od niego: „Zawsze coraz lepiej, ale w sposób zrozumiały".

Porównanie tych dwóch tekstów wydaje się wnosić wiele...

\footnotetext{
${ }^{30}$ K. Ludewig, Terapia systemowa, s. 19.

31 Tamże.
} 
Spójność i koherentność prezentowanej koncepcji - zarówno teoria, praktyka teorii, jak i praktyka - są dokonywane w ujęciu systemowym, zgodnie z rozumieniem zaproponowanym przez Maturanę, jak i jego ucznia K. Ludewiga. Całość stanowić ma dość jasną propozycję spojrzenia na relacje rodzice - nauczyciele. Co ważne, należy pamiętać, że nieobecnym - w sensie fizycznym - podmiotem owej relacji są zawsze dzieci i młodzież, bez których tych relacji by prawdopodobnie nie było. Poniżej rycina 1 ukazuje orientacje leczenia, które zaadaptowano do sposobu rozumienia interakcji rodzic - nauczyciel $^{32}$. Oś pionową stanowią pojęcia związane z celami, jakie stawia sobie osoba nauczyciel. Oś pozioma prezentuje interakcje między nauczycielem a rodzicem.

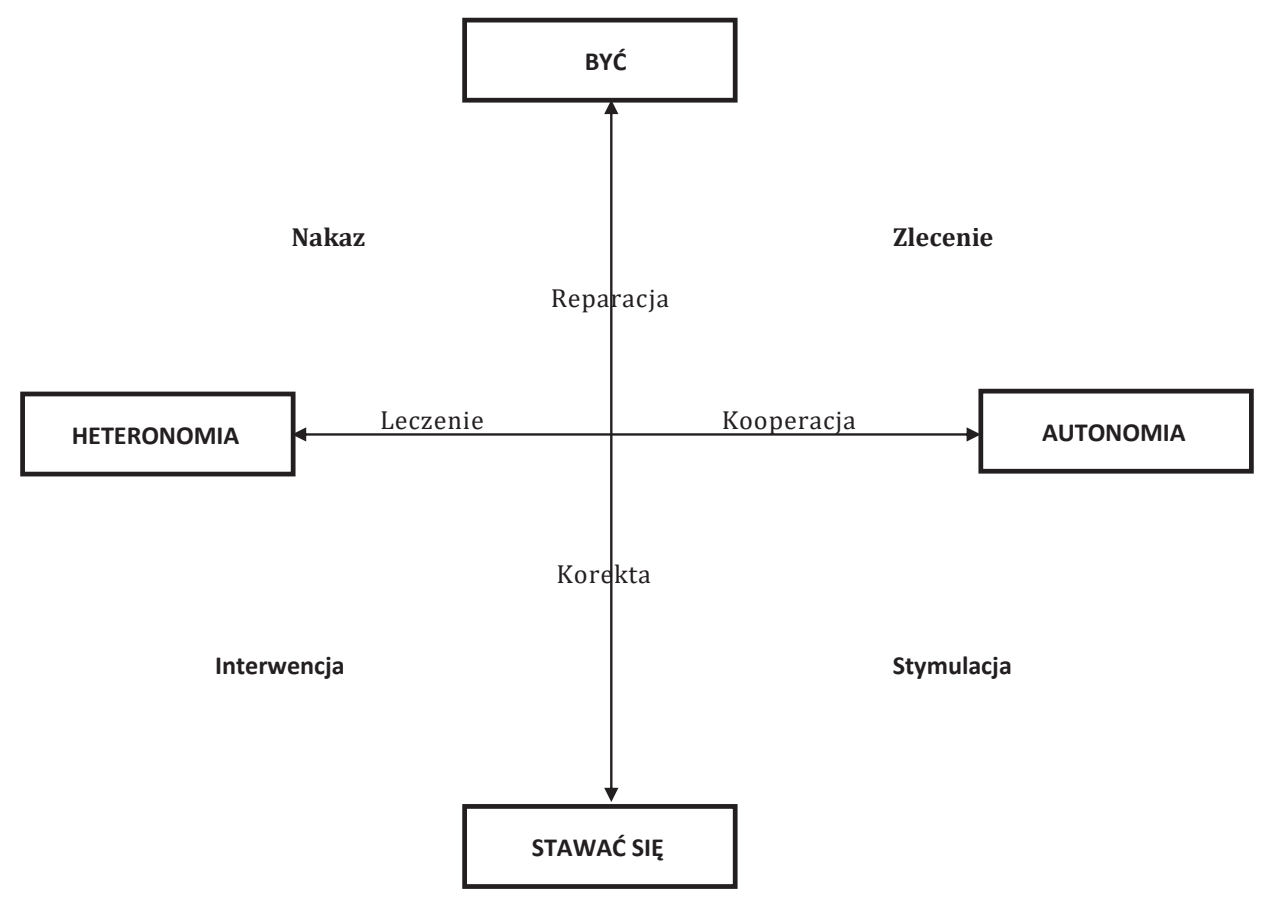

Ryc. 1. Orientacje leczenia

(źródło: K. Ludewig, Terapia systemowa, podstawy teoretyczne i praktyka, Gdańsk 1995, s. 20)

W przypadku nakazu i interwencji nauczyciel jest w roli eksperta - wydaje bezwarunkowe polecenia, wie lepiej. Są to interakcje instruktywne. Zdanie

${ }^{32}$ Tamże, s. 29-31. 
rodzica brane jest pod uwagę tylko wówczas, kiedy nie koliduje z założoną przez nauczyciela czy system koncepcją działań.

Nakaz - nauczyciel dąży do przezwyciężenia odstępstw od normalnego stanu, całkowicie przejmuje inicjatywę, samodzielnie podejmuje decyzje. Na przykład: zawiadamia prokuraturę czy policję o możliwości popełnienia przestępstwa wobec dziecka. Odmawia wydania go pijanemu rodzicowi, jednocześnie dzwoniąc do innego opiekuna, nakazując mu odebranie dziecka ze szkoły i uruchamiając dalsze procedury - zgodnie z regulaminem placówki.

Interwencja - jako zalecanie określonych oddziaływań, zobowiązuje nauczyciela do skorygowania odstępstwa od stanu optymalnego, zalecenia pewnych środków, o których akceptację przez rodzica musi on zabiegać. $\mathrm{Na}$ przykład: pójście do poradni psychologiczno-pedagogicznej, nakaz odrabiania z dzieckiem lekcji, nakaz przyniesienia zaświadczenia od lekarza, że dziecko jest zdrowe i może chodzić z nieokreśloną wysypką do szkoły.

W zaleceniu i stymulacji przyjmuje się założenie o większej autonomii w relacjach.

Zalecenie - nauczyciel stara się skorygować odstępstwa od stanu optymalnego, jednak uwzględnia indywidualność rodzica. Musi zadać sobie trud znalezienia argumentów, aby rodzic chciał kontynuować zalecane działania. Dostosowuje swoją wiedzę do możliwości rodzica. Rozmawia z nim, czy może udać się po rejonowej poradni psychologiczno-pedagogicznej szkoły, czy też z racji zmiany miejsca zamieszkania rodzic wolałby iść do innej. W rozmowie z rodzicem argumentuje na przykład, że mimo obiadu w domu, warto rozważyć obiady w szkole, skoro dziecko spędza w niej osiem godzin, proponuje możliwości (np. dofinansowania obiadów), pyta o ich ewaluację rodzica.

Stymulacja - to nawiązanie dialogu, który nie narusza podziału kompetencji. Obie strony wspólnie określają cel i metody, szukają alternatyw. Jak rozwiązać daną kwestię, kto, co i kiedy może zrobić? Jest to wspomniane wcześniej traktowanie rodzica jak eksperta. Zakłada dialog. Początkowo wydłużając czas zainwestowany przez obie strony, umożliwia podjęcie współdziałania i kooperacji.

Zazwyczaj w strukturach szkoły i jej kontekstu, a także relacji, częściej nauczyciele odwołują się do nakazu i interwencji, rzadziej do zaleceń i stymulacji. Zaakcentowana wyżej początkowa oszczędność czasu i wysiłku jest jednak tylko złudzeniem; heteronomicznie ujęty rodzic nie odzyska autonomii, będzie więc raczej niezadowolonym odwiedzającym, a nie kooperującym uczestnikiem dialogu.

Jak dalej konkluduje K. Ludewig, żadna orientacja nie występuje w stanie czystym, w praktyce jest mieszanką powyższych możliwości. Jednakże, przyjęcie takiego podziału i stosowanie go przez nauczyciela może ułatwić reflek- 
sję nad swoją pracą, a także koniecznością i sensownością podejmowanych działań. Oczywiste jest zatem - zgodnie z zasadą ekwipotencjalności - że te same zdarzenia wymagać mogą różnych orientacji działania. Są jednak pewne zdarzenia, gdzie stosowanie powyższego podziału będzie nie tylko użyteczne, ale też zapewni swego rodzaju komfort nauczycielom. Na przykład - że zrobili, co mogli, dostosowując swoje zachowania do sytuacji, kontekstu i responsywności drugiej strony.

Powyższy podział nie jest ocenny, nie pretenduje do orzekania co lepsze a co gorsze a priori. Pojawiają się bowiem liczne sytuacje, kiedy jedynym dostępnym wyjściem jest nakaz lub interwencja. Chodzi jednak, żeby zachować podmiotowość rodzica, aby mógł on przyjąć odpowiedzialność za swoje czyny wobec dziecka i struktury, której przedstawicielem jest rodzic, a także aby nauczyciel miał komfort pracy, zmniejszył ryzyko wypalenia zawodowego i związane z tym wielorakie konsekwencje.

\section{Podsumowanie}

Zgodnie z założeniami podejścia systemowego, każda zmiana w systemie pociąga za sobą zmiany u jego członków, choć nie można ich zdefiniować i dokładnie przewidzieć, stają się one faktami. Zmianę, która jest różnicą osiąga się - między innymi - poprzez wspólne ustalanie znaczeń, odbywające się podczas dialogu. Spotkanie w dialogu wymaga, aby jego uczestnicy szanowali zarówno własną, jak i cudzą wiedzę, doświadczenia oraz emocje, dzięki czemu możliwe będzie stworzenie relacji eksperckich. Relacje takie niosą w sobie duży potencjał - stymulując do aktywności, autonomii i poszukiwania wspólnych obszarów działania. Mimo powszechnej zgody wśród praktyków i/lub teoretyków działań edukacyjnych, pedagogicznych, opiekuńczo-wychowawczych, czy wszelakich - pomocowych, wciąż w strukturach polskiej szkoły pokutuje idea pedagogizacji rodziców. Zakłada ona - bez rozpoznania czego potrzebują owi konkretni rodzice i co warto by im zaproponować w odniesieniu do owego konkretnego dziecka - ideę przekazywania wiedzy, informacji, a czasami nawet kształtowania umiejętności, bez których to, jak sądzą propagatorzy pedagogizacji, rodzice sobie nie poradzą. Smutną konkluzją, nadal związaną z epistemologią i semantyką systemową, jest fakt, że działania te reguluje mechanizm dodatniego sprzężenia zwrotnego. Zatem, im bardziej nauczyciele starają się pedagogizować rodziców, tym bardziej oni nie poddają się tym działaniom. Pozostaje więc nie tyle zwiększyć zakres pedagogizacji, czy jej intensywność, co nie służy ani nauczycielom, ani rodzicom, ale zmienić formę owej interakcji. Uważany za bezsilnego i wymagającego kierowania rodzic nie 
stanie się po kilku instruktywnych spotkaniach autonomiczną i refleksyjną jednostką. Będzie oczekiwał cudownych rad, idealnej pomocy od wykształconego w tym obszarze i będącego w pozycji eksperta - nauczyciela. Sytuacja wydaje się o tyle ważna, że nauczyciele to statystycznie grupa zawodowa, która w ciągu swojej kariery zawodowej uczestniczy w największej liczbie dokształcania, $\mathrm{w}$ zestawieniu $\mathrm{z}$ innymi grupami zawodowymi. Jednak bardziej niż szkolenia: "jak radzić sobie z roszczeniowym rodzicem”, przydatne wydają się te związane z umiejętnością słuchania, rozmawiania w oparciu o zaciekawienie i wspólnym ustalaniu znaczeń, przy jednoczesnym szacunku do swoich granic i możliwości reprezentowanej instytucji. Zaprezentowanie w części końcowej modelu orientacji leczenia, zaadaptowanego do warunków szkolnych, zostało pomyślane jako pewnego rodzaju matryca, mogąca sprzyjać zarówno naukowym konstatacjom, jak i praktycznym działaniom.

\section{BIBLIOGRAFIA}

Bereźnicka M., Fora internetowe jako źródło informacji pedagogicznej wspótczesnych rodziców, [w:] Kultura informacyjna w ujęciu interdyscyplinarnym: teoria i praktyka, t. 2, red. H. Batorowska, Z. Kwiasowski, Uniwersytet Pedagogiczny im. Komisji Edukacji Narodowej, Instytut Bezpieczeństwa i Edukacji Obywatelskiej, Katedra Kultury Informacyjnej i Zarządzania Informacją, Kraków 2016.

Bis D., Rodzina jako podstawowe środowisko wychowania do korzystania ze środków społecznego komunikowania, Roczniki Nauk Społecznych, 2002, XXX, 2.

Błasiak A., Wspótpraca szkoty i rodziny jako istotny czynnik optymalizacji procesów wychowania i kształcenia najmłodszego pokolenia, Horyzonty Wychowania, 2017, 16, 38.

Chmura-Rutkowska I., Ostrouch J., Zakres i formy zaangażowania ojców w codzienne relacje z dziećmi, [w:] Kierunki dziatań w Polsce na rzecz równowogi praca-życie-rodzina, red. C. Sadowska-Snarska, Wydawnictwo Wyższej Szkoły Ekonomicznej, Białystok 2008.

Cywińska M., Sytuacje trudne w życiu dziecka, część I, Wydawnictwo Naukowe UAM, Poznań 2008.

Dell P.F., Why family therapy should go beyond homeostasis: A Kuhnian reply to Tyano, Carel and Ariel, Journal of Marital and Family Therapy, 1984, 10.

Dell P.F., Understanding Bateson and Maturana: toward biological foundation for the social sciences, Journal of Marital and Family Therapy, 1985, 11, 1.

Dzikomska-Kucharz A., Pedagogizacja rodziców - zadanie szkoły, Edukacja i Dialog, 2001, 3.

Dusza B., Sylwetka rodzica i jego wspótpraca ze szkota w oczach nauczycieli gimnazjum (doniesienie z badań), Edukacja - Technika - Informatyka, 2017, 2/20.

Hernik K., Malinowska K., Jak skutecznie wspótpracować i komunikować się z rodzicami i spotecznościa lokalna. Poradnik dla nauczycieli i dyrektorów, Instytut Badań Edukacyjnych, Warszawa 2015.

Izdebska J., Dziecko - dzieciństwo - rodzina - wychowanie rodzinne: kategorie pedagogiki rodziny w perspektywie pedagogiki personalistycznej, Wydawnictwo Niepaństwowej Wyższej Szkoły Pedagogicznej, Białystok 2015. 
Janke A.W., Transformacja w stosunkach rodziny i szkoły na przełomie XX i XXI wieku, Wydawnictwo Uniwersytetu Kazimierza Wielkiego, Bydgoszcz 2002.

Kawula S., Pedagogizacja rodziców, [w:] Encyklopedia pedagogiczna, Wyd. 1, red. W. Pomykało, Fundacja Innowacja, Warszawa 1993.

Kawula S., Kultura pedagogiczna rodziców: wyzwanie i czynnik stymulacji rozwoju młodego pokolenia Polaków, [w:] Edukacja prorodzinna. Księga dedykowana Profesorowi Marianowi Śnieżyńskiemu, red. M. Chymuk, D. Topa, Wydawnictwo Naukowe Akademii Pedagogicznej, Kraków 2000.

Kędra M., Włączanie rodziców w edukację dzieci http://sp8chelm.pl/images/galerie/ biblioteczka_dla_rodzicow/wlaczanie_rodzicow_w_edukacje_dzieci.pdf [dostęp: 11.10.2018].

Kołodziejczyk J., Cieślak H., Analiza wyników ewaluacji zewnętrznych w odniesieniu do wymagania "Rodzice sa partnerami szkoty", https://www.npseo.pl/data/various/files/ tom4_roz11.pdf [dostęp: 13.11.2018].

Kraus B., Introducing a Model for Analyzing the Possibilities of Power, Help and Control, Social Work \& Society, 2014, 12, 1.

Ludewig K., Terapia systemowa, podstawy teoretyczne i praktyka, Gdańskie Wydawnictwo Psychologiczne, Gdańsk 1995.

Lulek B., Powinności - Pozory - Inicjowanie działania. Wyznaczniki relacji rodziców z nauczycielami w szkołach podstawowych, Kultura - Przemiany - Edukacja, 2017, V.

Łukasik J.M., Solecki R., Aktywność młodzieży w Internecie a relacje z rodzicami. Wskazania dla nauczycieli do pedagogizacji rodziców, Rocznik Lubuski, 2017, 43, 1.

Maturana H.R., Poerksen B., The view of the systemicist: a conversation, Journal of Constructivist Psychology, 2004, 17.

Miąso J., Starcie paradygmatów technologii informacyjnych i komunikacji interpersonalnej bezpośredniej wyzwaniem dla człowieczeństwa, społeczeństwa i edukacji, Edukacja - Technika - Informatyka, 2015, 3(13).

Musioł M., Pedagogizacja medialna rodziny: zakres - uwarunkowania - dylematy, Wydawnictwo Uniwersytetu Śląskiego, Katowice 2013.

Ordon U., Gębora A.K., Partnerskie relacje rodziny i szkoty w tworzeniu optymalnych warunków procesu edukacji, Pedagogika Przedszkolna i Wczesnoszkolna, 2017, 5, 1(9).

Rokicka-Hebel M., Aktywność wolnoczasowa dzieci w wieku przedszkolnym i ich rodziców, Rocznik Naukowy Akademii Wychowania Fizycznego i Sportu w Gdańsku, 2014, XXIV.

Segiet W., Rodzice - nauczyciele. Wzajemne stosunki i reprezentacje, Wydawnictwo Książka i Wiedza, Warszawa 1999.

Segiet K., Dziecko i dzieciństwo jako wartość a wspótczesność, Chowanna 1, 2010.

Segiet K., Dziecko i jego dzieciństwo w perspektywie naukowego poznania i doświadczania rzeczywistości. Studium pedagogiczno-społeczne, Wydawnictwo Naukowe UAM, Poznań 2011.

Segiet W., O zwiazku edukacji z rodzina. Społeczne konteksty i jednostkowe biografie, Wydawnictwo Naukowe UAM, Poznań 2013.

Segiet K., Słupska K., Zmiany w funkcjonowaniu wspótczesnej rodziny $i$ ich konsekwencje dla rozwoju młodego pokolenia, Pedagogika Społeczna, 2013, 3(49).

Szczerbińska B., Zeszyt kontaktów jako narzędzie komunikacji szkolnej, Kształcenie Językowe Dydaktyka Polonistyczna, 2017, 3(12).

Zielińska M., Interpersonalne kontakty nauczycieli z rodzicami w dobie dziennika elektronicznego, Edukacja - Technika - Informatyka, 2017, 3(21).

Żołądź-Strzelczyk D., Dziecko w dawnej Polsce, Wydawnictwo Poznańskie, Poznań 2002. 


\section{Netografia}

https://www.cbos.pl/SPISKOM.POL/2014/K_093_14.PDF [dostęp: 09.09.2018].

https://www.cbos.pl/SPISKOM.POL/2009/K_121_09.PDF [dostęp: 10.10.2018].

http://www.pbp.poznan.pl/node/355 [dostęp: 13.10.2018].

ww.pbw.kielce.pl/userfiles/file/nowe_zestawienia/dokument138.pdf [dostęp: 13.09.2018]. 